\title{
Status of Yacht Industry in China and its Capital Preservation and Appreciation
}

\author{
Li-Feng WANG ${ }^{1, a}$, Chao-Yu ZHENG ${ }^{2, b}$, Wu CHEN ${ }^{2, c, *}$ \\ ${ }^{1}$ School of Business Administration, Jimei University, \\ Xiamen City 361021, Fujian Province, China \\ ${ }^{2}$ School of Marine Engineering, Jimei University, \\ Xiamen City 361021, Fujian Province, China \\ wlf2515@163.com, ${ }^{b}$ cyzheng@jmu.edu.cn, ${ }^{2 j m u c r u i s e @ 163 . c o m ~}$
}

Keywords: Yacht industry, Status, Capital Preservation and appreciation, Suggestions.

\begin{abstract}
The yacht industry is an important part of the emerging new type of ocean industry system in China and is getting much support from China state and local governments. In the coming years, the yacht industry in China is expected to usher in explosive growth and becomes a new focus of the world's yacht industry. However, the development of yacht industry in China still faces many challenges and problems. In this article, the status of yacht industry in China is analyzed in order to help understand the development level of China yacht industry and its challenges including the disadvantage of capital value for yacht industry. Meanwhile, the suggestions or ways to realize the capital preservation and appreciation for yacht industry in China are provided in order to promote the development of yacht industry.
\end{abstract}

\section{Introduction}

The yacht industry is a "five-intensive" industry that is labor-intensive, technology-intensive, capital-intensive, knowledge-intensive, and culturally intensive, it includes the design and manufacture of yachts, yacht parts and components manufacturing, construction of yacht marinas, yacht club operation and management, yacht driver's license training and assessment, yacht repair and maintenance, and yacht financial insurance, and other related industry chain. The yacht industry, being an important part of the emerging new type of ocean industry system, is getting much support from China state and local governments. The yacht manufacturing is attributed to the high-end equipment manufacturing industry which is one of the China seven strategic emerging industries. It has received great attention and strong support from the country. For example, in September 2015 the Ministry of Industry and Information Technology and other six ministries of China jointly issued the regulation to develop yacht industry to meet the yacht mass consumer demand, to develop vigorously the small and medium-sized yacht, and to promote the development of domestic yacht segment consumer market [1]. Yacht maritime leisure tourism is becoming a new type of leisure tourism in China and also has been cultivated greatly by the central and local governments. For example, in August of 2015 the State Council issued the related regulation and clearly proposed to nurture the development of yacht tourism market for mass consumer, the initial formation of interconnected yacht leisure travel network [2].

\section{Status of Yacht Industry in China}

Market participants believe that in the coming years, the yacht industry in China will usher in explosive growth, and the yacht tourism can not only realize the rapid development of tourism itself, but also drive the rapid growth of China's yacht manufacturing industry, providing new opportunities and broad market space for the development of China's yacht industry.

\section{Scale of Yacht Industry}

In China the per capita GDP of more than 20 cities located in the developed coastal areas has reached more than 8,000 US dollars and has exceeded the tipping point of rapid growth of yachts between 
5,000 and 6,000 US dollars. At present, there are more than 150 yacht clubs, nearly 10,000 water berths, and about 2700 dry cabins nationwide. More than 8 meters of commercial recreational yachts hold between 3,700 and 4,000 vessels; more than 5 meters of fishing boats, sailing ships and speedboats hold 14,000 vessels, and the total number of yachts in China totals about 17,000.

According to "2013-2017 China Yacht Investment Analysis and Forecast Report" released by the China Investment Advisory Network [3], with the rise of emerging markets such as China, Russia, and the Gulf countries, the trend of the economic gravity center of the future yacht industry is clearly shifting. From 2014, the China yacht industry will maintain a market growth rate of no less than 30\% per year, China is expected to seize the opportunity to welcome the future transfer of the yacht industry and become a new focus of the world's yacht industry. According to the forecast of the China Shipbuilding Industry Association, the scale of the China yacht market will reach 50 billion Yuan by 2020, and in the next 5 to 10 years the demand for yacht by Chinese companies and the wealthy will exceed 100,000 vessels [4].

\section{Yacht Manufacturing Industry}

At present China has become the sixth largest manufacturing country of yachts worldwide. According to the statistics of the China Cruise and Transportation Association's Cruise Yacht Club, after more than 30 years of development, there are currently nearly 500 yacht manufacturing and spare parts manufacturing companies in China, more than 30 of them with an annual output value of over 10 million Yuan. Among them, about 400 companies mainly produce yacht spare parts and equipment, and about 90 companies mainly build yachts. Their products cover mainly 5 to 90 meters of yachts, and their production capacity is still growing. In 2015, the scale of yacht production in China was close to 8 billion Yuan. China-made yachts have been exported to more than 70 countries and regions. However, China's yacht manufacturing industry is still in its infancy and technology is lagging behind. Most of yacht production enterprises adopt the production and management mode of "processing and assembly factories". This is a primary development mode that focuses on the consumption of resources, the environment, and the labor force. The yachts designed and manufactured are still mainly low-end products. The design and supporting materials of those domestic high-end yachts, are mainly imported from foreign countries, in other words, the core technologies of the China yacht industry (design, materials and equipment support) are still in the hands of foreign companies and lack core competitiveness.

\section{Yacht Maritime Leisure Tourism}

Yacht maritime leisure tourism is based on yacht to carry out marine tourism, leisure and entertainment, sea sports, marine fishing and other activities. Yacht maritime leisure tourism is becoming a new type of leisure tourism in China and an important part of the national marine economy and the emerging economic growth point, but also helps to promote the construction of marine culture to achieve the strengthening ocean strategy. Taking the Wuyuan Bay yacht wharf in Xiamen City as an example, according to the statistics by the yacht marina, the yacht wharf has the total passenger flow to experience the yacht maritime leisure tourism, of about 50,000 people in 2014, of 200,000 in 2015 , and reaching more than one million people in 2016, with an increase of $400 \%$. If the per capita consumption rate for one people to experience of yacht tourism in Xiamen is 3,000 Yuan, the one million visitors will bring 3 billion Yuan in consumer spending [5].

\section{Way to Maintain and Increase the Capital Value of the Yacht Industry}

As discussed above and in the previous related article series, at present the scale of the yacht industry in China is relatively small, highlighting the weak financial capital of the industry; meanwhile, the human capital of the yacht industry is scarce and the accumulation of capital from the organizational structure of the yacht industry is slow. Moreover, In China the definition of customer capital in the yacht industry is too narrow. These capital disadvantages of China's yacht industry are obvious. Only by solving the capital problem of the yacht industry can we promote the maintenance and appreciation of capital and clear the way for the development of the yacht industry from the root. 


\section{Change Yacht Consuming Attitude}

The consuming attitude of yacht should be changed to solve the capital dilemma of the yacht industry. The consuming of yachts in the world has turned to the stage of mass consuming, and the consuming of yachts in China has also seen a blowout in 2016. Taking Xiamen City as an example, the number of yacht sailing tourism receptions exceeded 2 million in 2016, an increase of 400 percent over the same period of last year, and the popularity of yacht consumption has gained significant momentum. The primary premise for the mass consumption of yachts is to eliminate the high barriers to the purchase and maintenance costs of yachts, so that more groups and individuals who are financially and technically disadvantaged have the opportunity to participate in the yachts and become the client capital of the yacht industry. Conceptually, the concept of changing yacht consumption as luxury consumption is to re-examine the current system and business philosophy of the government and the company (club) so that the yacht industry can serve the public. Institutional, redefining the concept of yacht isolated yacht ownership and use rights, property rights yacht to expand the scope, clearly define the rights and responsibilities of different ownership entities, rationalize the supervision and operation authority of different departments, and differentiate and gradually liberalize the yacht operation and consumption areas according to the differences in the qualification certification. In products, we will transform product design concepts to cater for mass consumer demand and expand the provision of mid- and low-end yacht products and services. Combining with the tourism industry, we will develop yacht services products such as experience tours, sea fishing, and string island tours for mass consumption.

\section{Improve Talent Training Mechanism for yacht Industry}

The talent training mechanism for yacht industry should be improved to reserve talents for its development. First, we must establish a talent training mechanism. A yacht design professional may be established in a member of the National Union of Shipbuilding and Ocean Engineering Universities, in particular a comprehensive university that also has related arts, materials, and other related majors, building an innovative experimental platform for yachts, and provide advanced technical talents for the yacht industry through academic and research collaboration to provide technical support. The second is to improve the talent training system. The technical requirements for the production and consumption of yachts are ensured by a sound personnel training system. The training system shall provide regular and systematic training courses according to the technical and development needs of the yacht industry, and provide sufficient mechanics, marketing personnel and service support personnel for the development of the yacht industry. The training system can use the training systems of universities, enterprises, and clubs to change the original training system that is based solely on technical training. Through combining the requirements of yacht leisure service industry to enrich the training content the traditional concept of mass yacht consumption would be changed. The government must provide transportation for yacht personnel, put forward clear requirements for the qualifications of yacht personnel in different areas, and conduct strict inspections to eliminate potential safety hazards at the source. The third is to accelerate the introduction of high-level yacht talents. Talent training takes time. A shortcut to solve the rapid development of the current yacht industry is talent introduction. The government and relevant units can set up special funds, formulate counterpart policies, and support the gathering of high-end yacht innovation and entrepreneurial talents through the introduction and cooperation to remove obstacles to the flow of talents.

\section{Open Up Yacht Rentals in China}

The yacht rental business is still prohibited in China according to the related laws and regulations, which to a great extent restricts the rapid development of the yacht industry. Yacht leasing is a quick and effective means to solve the capital bottleneck of the current yacht industry. Yacht leasing can not only allow more funds and talents to enter the yacht industry, but also can reduce the yacht consumption threshold and attract more consumer groups. In view of this, it is necessary to lift the policy and institutional shackles that yachts cannot be used for leasing operations, speed up the 
research and development of "means for the management of yacht leasing operations," and make yacht rentals available. Specifically, the following issues should be solved: First, the qualifications and audits of yachts and yacht operators. Through the qualification review, different types of yacht operation and consumption thresholds are established; second, defining the yacht rental business model. By clarifying the rights and obligations between the renter and the lessee, the operating mode of the yacht operating unit under different lease modes is given; Third, the establishment of the yacht rental supervision system. Clarify the duty of the regulatory authorities and to further rationalize the system of administrative supervision of the yacht industry, innovative sound management and supervision mechanism, in order to ensure that the yacht operators carry out legal, orderly and safe yacht charter; Forth, to establish a yacht rental guarantee system. Study and improve the yacht financing guarantee system, explore the establishment of a yacht rental industry fund, try to produce a highly-targeted lease-type yacht that is specifically applicable to leasing operations, and actively create a guarantee system for the healthy, sustained and rapid development of yacht rentals.

\section{Strengthen Construction of Yacht Platform and Infrastructure}

The construction of yacht platform and infrastructure should be strengthened to lay a solid foundation for the development of the yacht industry. First of all, investigate and sort out the shoreline resources of the marina. According to the functional orientation, it will improve the planning of yacht marinas and active water areas, accelerate the construction of public yacht marinas, improve the service support capabilities of piers and other infrastructure facilities, and meet the needs of berthing, maintenance and maintenance services for popular yachts. Secondly, to revise the rules for the management of yachts entering and leaving the country, set up the open yacht ports, formulate plans for the opening of yachts at ports, and solve the problem of entry and exit of foreign yachts. Thirdly, study the establishment of a comprehensive bonded zone for yachts and solve the high tax burden on yachts through preferential policies in the bonded area. Fourthly, improve the yacht maintenance and maintenance system, formulate the training plan for maintenance and technical personnel in a graded manner and improve its technical application level; classify and plan the protection functions of different terminals, and strengthen the safety requirements for yacht operations. Fifthly, build an information service platform for yachts based on the advantages of the Internet. Create customs, border inspection, maritime affairs, public security, and entry-exit inspection and quarantine departments for the joint transport inspection mechanism to simplify customs procedures; create a ground public service information platform to realize yacht intelligent supervision and service intelligence; create a yacht public service information platform that integrates yachts, yacht clubs, management agencies and consumers with instant information, internal and external interactions, optimize the allocation of yacht resources, promote the spread of yacht culture, and promote the popular consumption of yachts.

\section{Summary}

The yacht industry in China is developing rapidly and becoming a new emerging growth point for the China's ocean economy. However, there are many obstructions for the development of yacht industry in China. The various above-mentioned challenges and shortage of various types of capital for the industry should be solved thoroughly. In practice the related administration departments should actively take the above-mentioned measures or ways to substantially increase the total capital of the yacht industry. Only when the total capital increases enough large to meet the needs of industrial development can we fundamentally explore the development potential of the yacht industry in China and promote the rapid development of the yacht industry.

\section{Acknowledgement}

This research was financially supported by the High-level Technical Talent Training Project for Transportation Industry in China. 


\section{References}

[1] Opinions on Promoting the Development of Tourism Equipment Manufacturing Industry. Ministry of Industry and Information, China. 2015, No. 331, 2015-9-28.

[2] Several Opinions on Further Promoting Tourism Investment and Consumption. General Office of the State Council, China. 2015, No. 62, 2015-8-11.

[3] Information on http://www.ocn.com.cn/.

[4] L.C. Zhao, X.N. Shang. Study on the Development Status and Support System of Yacht Industry in Sanya City [J]. Marine economy, 2017, 7(2):43-48.

[5] L.F. Wang, Y.F. Xiong, Q.L. Chen, C.Y.Zheng. The Bottleneck of the Development of Yacht Maritime Leisure Tourism in Fujian and its Countermeasures [C]. Proceeding of the 3rd Annual International Conference on Management, Economics and Social Development, 2017: D231. 